\title{
Introductory editorial thematic issue: Mediterranean karst hydrogeology
}

\author{
Francesco Fiorillo $^{1} \cdot$ Zoran Stevanović $^{2}$
}

Received: 4 April 2015/Accepted: 19 May 2015/Published online: 29 May 2015

(C) Springer-Verlag Berlin Heidelberg 2015

This Special Thematic Issue of Environmental Earth Sciences (EES) is a collection of contributions from authors of the Mediterranean region in the specific field of karst hydrogeology. The editors invited well known researchers from Mediterranean countries, some of whom are members of the International Association of Hydrogeologists (IAH) Karst Commission, and encouraged them to provide a general or case history paper. Apologies are made to authors who were not invited with the hope to involve them in future projects.

The idea to have such an issue originated during a meeting organised by the IAH-Italian Chapter in preparation for the 42nd Congress of IAH to be held in Rome in September 2015 (AQUA 2015). This opportunity is taken to thank the President of the Organising Committee of the IAH Congress, Marco Petitta, (University of Rome "La Sapienza") and Jo de Waele (University of Bologna) who have supported the idea and facilitated arrangements for this Special Thematic Issue. Support of the Editor in Chief of EES, James LaMoreaux, who approved the idea and followed up the publication process, is gratefully acknowledged. Thanks are also given to the Italian IAH Chapter, University of Rome "La Sapienza" and University of Sannio, which supported this issue. Finally, papers

Francesco Fiorillo

francescofiorillo@libero.it; francesco.fiorillo@unisannio.it

Zoran Stevanović

zstev_2000@yahoo.co.uk; zstevanovic@rgf.bg.ac.rs

1 Dipartimento di Scienze e Tecnologie, Università degli Studi del Sannio, via dei Mulini 59/A, 82100 Benevento, Italy

2 Head of the Centre for Karst Hydrogeology, Faculty of Mining and Geology, Centre for Karst Hydrogeology, University of Belgrade, Djusina 7, 11000 Belgrade, Serbia in this issue provide material that complements the Guides for several of the excursions organised on the occasion of this congress. Interest in karst aquifers continues to increase worldwide mainly because groundwater resources in these environments are generally more abundant than those in other environments which have been greatly exploited. In Mediterranean countries research in the field of karst hydrogeology has a long history and most methods have been applied and/or developed in various case studies in this region.

The importance of karst aquifers in the Mediterranean area also relates to locally specific climatic conditions, characterised by long, dry and hot summers. Especially in the southern and eastern parts of the Mediterranean, the dry period could extend more than 6 months while in contrast the wet period could be reduced to 1-2 months. In such a climatic context variation of groundwater reserves in karst aquifers and the deficit of water in waterworks during dry periods (summer-autumn) is more the rule than the exception. Many engineering master works have been constructed in the past with the aim of regulating karst aquifer regimes; protecting fresh ground water from sea water intrusion; or keeping vulnerable karstic waters from uncontrolled pollution.

These attempts have had great importance in the historical and economic development of the Mediterranean area as well as its civilization. The most powerful karst springs were easily tapped, and gravity channels allowed water to be supplied to high concentrations of people. Most large towns along the shoreline built up in the vicinity of large karstic springs. Ancient Rome and its empire are probably the most significant example: powerful karst springs fed ancient aqueducts, supplying large quantities of water for towns, villages, harbours, thermes and pools. More than $13 \mathrm{~m}^{3} / \mathrm{s}$ of water flowed during that time 
towards the city centre. Karst aquifers continue today to supply millions of inhabitants with water around the Mediterranean basin. In some zones they constitute the single available water resource. This resource is also of crucial importance for touristic and economically sustainable development.

This issue contains 20 articles from European, African and Asian Mediterranean countries. Although several papers discuss transboundary sites, roughly six papers from Italy, two each from Spain and France, and one each from Slovenia, Croatia, Serbia, Bosnia and Herzegovina, Montenegro, Albania, Greece, Turkey, Algeria and Morocco are distinguishable as such.

Contributions deal with various specific aspects of karst hydrogeology: fresh groundwater tapping, sea water intrusion, anthropogenic contamination, recharge, spring discharge analyses, time series analyses, climate change impacts, and engineering. Also covered are the diversity of karstic features and various conditions for their development. This is shown in the statement of M. Bakalowicz that "because of the complexity of karst development in Mediterranean regions, it is unrealistic to expect to manage them in a sustainable way without a thorough assessment of local karst aquifers".

Tours through Mediterranean karst may start in the Classical Carso area in northeastern Italy, the northernmost part of the famous Dinaric karst. The scientific term Karst even originated there primarily thanks to Jovan Cvijić's works. P. Milanović in his contribution emphasizes that basic ideas related to the nature of karst are created from the multidisciplinary and long-term investigations in this particular region. World famous karstologists such as Cvijić, Grund, Katzer and many others created crucial theories of karstology based on analysis of the Dinaric Karst.

O. Bonacci presents many examples of karst water phenomena from the Dinaric karst (estimated on its surface to be about $60,000 \mathrm{~km}^{2}$ ) including springs, open stream flows and their regime, lakes and wetlands, and coastal and island karst.

Abundant fresh groundwater resources of the Dinaric and adjacent Pindes Mountains karst are confirmed in the paper of R. Eftimi and H. Zojer. It is estimated that renewable karst water resources in Albania $\left(6750 \mathrm{~km}^{2}\right)$ are about $227 \mathrm{~m}^{3} / \mathrm{s}$ which is $80 \%$ of Albania's national groundwater resources. Considerable hidden groundwater flow in this region is stated in the contribution of M.M. Radulović et al.: sublacustrine fresh groundwater drainage into the Skadar Lake shared between Montenegro and Albania is $10 \mathrm{~m}^{3} / \mathrm{s}$ on average. P. Marinos and A. Kallioras describe the main Greek karst aquifers, focusing on the Boeoticos Cephissus basin, a wide area $\left(2000 \mathrm{~km}^{2}\right)$ of
Central Greece where karst aquifers constitute the boundaries and substratum.

E. Gilli discusses one of the major problems in Mediterranean karst-salt contamination of karst aquifers along the shoreline. Based on several examples from southeastern France, southern Spain and the Greek islands he emphasizes the problem of properly tapping fresh water. M. Polemio et al. describe the seawater intrusion of Apulia Peninsula, amplified by well exploitation, and evaluate future conditions under different climate change scenarios. Not only does salt contamination affect quantity and quality in coastal areas, but also high anthropogenic pressure causes "the need for harmonized multi-country policies regulating resources abstraction and contamination issues", according to N. Ravbar and G. Kovačič.

Historical aspects of utilizing water resources in karst of the southern Apennines are discussed in the paper of $\mathrm{M}$. Parise and Sammarco. The contribution of F. Fiorillo et al. bring us from the past to think more about future and climate changes impact: spring discharges in Central-Southern Italy can be assumed to be a robust indicator of climate change as it integrates the effects of precipitation and temperature variation. Karst of southern Italy is also discussed in the contribution of F. Celico et al. but from the point of view of aquifer vulnerability and microbial contamination.

Karst of southern Spain is evaluated in contributions of A. Pulido-Bosch et al. and D. Sanchez-Garcia et al. The former discusses anthropogenic impacts on water quality and construction in the saturated zone, while the latter highlights the importance of hydro-geochemical methods. These methods can be a useful tool in groundwater management in sensitive environments (wetlands, coastal aquifers) and present dependent ecosystems.

Karst of Near East and Taurides, its features and water resources are evaluated in the contribution of G. Gunay et al. Furthermore, karst of the Zagros and the Carpathian Mountains, adjacent regions to the Mediterranean basin, is used by Z. Stevanović et al. to explain the importance of considerable storage capacity in deeper aquifers. This helps to attenuate the effects of climate variations and of severe droughts.

Karst of the Atlas Mountains is discussed in the contribution of F. Chemseddine et al. and of B. Akdim. The former studied groundwater origin in the Tezbent Mountains near Tebessa while the latter focused on the human impact on Moroccan karst and the need for sustainable management of present natural resources. In contrast with these semiarid karst areas of North Africa, Vigna and Banzato describe karst springs of wet mountain areas of the western Alps, highlighting the role of snow accumulation and different types of aquifer karstification. 
To end the tour of Mediterranean Karst the special thematic issue returns to the Dinaric and Carso area. Many large successfully constructed structures (dams, reservoirs and tunnels) of that region became the basis for the development of engineering karstology in the second half of the 20th Century. Others currently being implemented, such as part of Corridor V, will connect Portugal and Ukraine crossing this region in the process. F. Cucchi et al. consider the importance of basic research and karstification to the degree of knowledge when planning such infrastructure projects.
Finally, all contributions published in this unique special thematic issue provide an exciting purview into some of the most famous karst in the world. The issue is unique in that it is being published before the IAH 2015 Congress in Rome serving as an introduction to the conference and raising awareness of it in the scientific and lay public communities. Perhaps it will be a model for special thematic issues dedicated to future events in the earth sciences. 